\title{
Analysis of Prognostic Factors in Bladder Carcinoma Treated With Radical Cystectomy
}

\author{
Mesane Kanserinde Radikal Sistektomi Sonrası Prognostik Faktörlerin Değerlendirilmesi
}

\author{
Sümer Baltacı', Çağatay Göğüş', Kadir Türkölmez1, Yaşar Bedük', Gül Ergün², \\ Berkan Reşorlu
}

'Ankara Üniversitesi Tip Fakültesi, Üroloji Anabilim Dal ${ }^{2}$ Hacettepe Üniversitesi, Istatistik Bölümü

${ }^{3}$ Keçiören Eğitim ve Araștırma Hastanesi, Üroloji Anabilim Dalı
Received: 18.05.2009 • Accepted: 20.06.2009

Corresponding author

Uzm. Dr. Berkan Reşorlu

Keçiören Eğitim ve Araştırma Hastanesi, Üroloji Anabilim Dalı

Phone $+90$

E-mail address : drberkan@yahoo.com
Aim: To evaluate variable prognostic factors which might affect disease-specific survival in patients who have undergone radical cystectomy and pelvic lymphadenectomy for bladder carcinoma.

Methods: We retrospectively reviewed 241 consecutive patients with invasive bladder carcinoma between 1990 and 2008, all had radical cystectomy. The clinical and pathological data and clinical outcome were evaluated. The Chi-square test was used to determine the significance of the relationship between the clinical and pathological findings. While disease-specific survival and the association between patient's parameters and survival were analyzed using Kaplan-Meier method and long-rank test respectively.

Results: Considering the type of urinary diversion, 97 patients had ileal conduit; 58 patients had orthotopic bladder using ileal segment; and orthotopic mainz pouch was applied to 43 patients. While ureterocutaneostomy and ureterosigmoidostomy were the choice in 22 and 21 patients respectively. The mean age of the patients at receipt of the surgical procedure was 59.8 years (range from 29 to 83 years) and the mean follow-up interval was 34 months (median follow up: 22, SD: 36.66; range from 1 to 175 ) for patients alive at last follow-up. According to the pathological stage, the 5 -year survival rate was found to be $72.9 \%, \% 77.6 \%, 48.0 \%, 25.4 \%$ and $28.8 \%$ for pT0, pT1, pT2, pT3 and pT4 respectively. (Figure 1; log-rank test, $\mathrm{p}<0.001$ ). Moreover, it is found that $6.5 \%, 11.5 \%, 16.7 \%, 49.1 \%$ and $48.6 \%$ were the local recurrence and/or metastasis rate for pT0, pT1, pT2, pT3 and pT4 respectively $(\mathrm{p}<0.001)$. It is seen that lymph node involvement obviously rise with the advance in pathological stage. In another word, the rate of having nodal metastasis was significantly higher in patients with pT3 or more (pT3: $26.3 \%$, pT4: $20 \%$ ) than in those with pT2 or less (pT0 and pT1:0\%, pT2:6.1\%), $(p<0.001)$. On univariate analysis, patient's age, presence of tumor-related hydronephrosis, lymph node status, pathological stage and grade were significant predictors of disease-specific survival.

Conclusions: In this study, it is clearly shown that good results could be obtained if radical cystectomy is the treatment of choice for patients with early diagnosed invasive bladder carcinoma.

Key Words: bladder cancer, radical cystectomy, prognosis

Amaç: Innaziv mesane tümörlerinin tedavisinde bugün için standart tedavi yöntemi radikal sistektomidir. Bu çalışmada, invaziv mesane kanseri nedeniyle radikal sistektomi yapılan 241 hastadaki cerrahi deneyimlerimiz ve uzun dönem takip sonuçlarımız sunulmaktadır.

Materyal ve Metodlar: Kliniğimizde 1990 yılından itibaren invaziv mesane kanseri nedeniyle radika sistektomi yapılan 241 hastanın (214 erkek, 27 bayan) kayıtları retrospektif olarak incelenmiştir. Klinik ve patolojik verilerle birlikte, hastaların takip sonuçları da değerlendirilmiştir. Kategorik değişkenler arasındaki ilişkilerin araştırılmasında ki-kare testi kullanılmıştır. Sağkalım oranları Kaplan-Meier metodu ile, hastaların özellikleri ve sağkalım arasındaki ilişki de log-rank testi kullanılarak belirlenmiştir.

Bulgular: Üriner diversiyon tipi olarak 97 hastaya ileal konduit, 58 hastaya ileum segmenti ile ortotopik üriner diversiyon, 43 hastaya mainz pouch II, 22 hastaya üreterokutanostomi ve 21 hastaya ise üreterosigmoidostomi uygulanmıştır. Hastaların ortalama yaşı 59.8 (29 ve 83 yıl arasında) yıldır. Patolojik evrelere göre 5 yıllık genel sağkalım oranları pT0, pT1, pT2, pT3 ve pT4 için sırasıyla \%72.9, \%77.6, \%48.0, \%25.4 ve \%28.8 olarak tahmin edilmiştir (Şekil 1; log-rank test, p<0.0001). Patolojik evrelere göre ameliyat sonrası lokal nüks veya uzak metastaz gelişme oranları pT0, pT1, pT2, pT3 ve pT4 evreleri için sırasıyla \%6.5, \% 11.5, \%16.7, \%49.1 ve \%48.6 olarak bulunmuştur $(p<0.0001)$. Lenf nodu tutulumu da patolojik evresi daha yüksek olan hastalarda artmaktadır. Lenf noduna metastaz pT3 ve daha ileri evre hastalığı olanlarda (pT3: \%26.3, pT4: \%20), pT2 ve daha düşük evre hastalığı olanlara (pT0 ve pT1: \%0, pT2: \%6.1) göre anlamlı bir biçimde daha yüksektir $(\mathrm{P}<0.0001)$.

Sonuçlar: Bu seridede görüldüğü gibi radikal sistektomi erken dönem invaziv tümörü olan hastalarda oldukça iyi sonuçlar vermektedir. Ancak mesane dışına çıkmış metastatik olmayan hastalıkta radikal sistektomi her zaman yeterli olamamaktadır.

Anahtar Kelimeler: mesane kanseri, radikal sistektomi, prognoz 
Bladder carcinoma is the fourth most common cancer in men and the eighth most common cancer in women worldwide(1). Bladder carcinoma occurs predominantly in older patients and 20-40\% of patients with transitional cell carcinoma (TCC) of the bladder will present with or develop muscle invasive disease (2). Currently, radical cystectomy with bilateral pelvic lymphadenectomy is the primary treatment modality in individuals with muscle invasive or refractory, high grade superficial bladder carcinoma (3). Invasive tumors that are confined to the bladder musculature on microscopy of radical cystectomy specimens have approximately 50 to $75 \%$ 5-year progression-free survival rate (4). An accurate prediction of clinical outcome is important for tailoring the optimal treatment regimen for patients with malignant disease. The major prognostic factors of invasive bladder carcinoma are the depth of invasion into the bladder wall (stage) and the degree of differentiation of the tumor (grade). Other factors like lymph node status, lymphovascular invasion, tumor size, patient age and tumorrelated hydronephrosis are present $(5,6)$.

The objectives of the present study are the analysis of the results of radical cystectomy-treated bladder carcinoma patients and the determination of prognostic factors which can be used as mortality.

\section{Material and Methods}

We retrospectively reviewed the records of 241 patients who had undergone radical cystectomy, pelvic lymphadenectomy and urinary diversion for bladder carcinoma at our department between 1990 and 2008. Data were collected from retrospective reviews of hospital and physician's office records and from patients' interviews during follow-up visits. Preoperative evaluation included physical examination, chest radiography, complete blood count and blood urea nitrogen determination. Abdominal ultrasonography (US) and computed tomography (CT) were used for clinical staging. When indicated, bone scan was also performed. The tumor stage and grade were recorded according to the 2002 TNM system and the World Health Organization system, respectively. Indications for radical cystectomy included muscle-invasive bladder carcinoma, or non-muscle invasive disease refractory to intravesical chemotherapy and/or immunotherapy. Virtually no patient had distant metastatic disease at the time of cystectomy. The methodology and surgical procedures involved in radical cystectomy remained unchanged during the study period. In men, the bladder, prostate, and seminal vesicles were resected; while in women, the bladder, anterior vaginal wall, uterus and in older women overs were removed. Urethrectomy was only performed in men with histologically-proven cancer of the prostatic urethra prior to radical cystectomy or per-operative tumorpositive frozen examination of the urethral margin. The patients were initially seen 1 month after surgery; then every 3 months for the first year; every 6 months for the second year; and annually thenafter. Follow-up visits consisted of a physical examination and serum chemistry evaluation. Diagnostic imagings were performed at least annually or whenever clinically indicated.

All statistical analyses were obtained using SPSS. The chi-squared test was used to evaluate the association between categorical variables.
Differences in variables with a continuous distribution across dichotomous and ranked categories were assessed using the Mann Whitney U-test and the Kruskal-Wallis nonparametric analysis of variance, respectively. Univariate and multivariate survival analyses were performed with the aid of Cox proportional hazard regression model. Cancer-specific survival rate was determined by the KaplanMeier method, and the differences were determined by the log-rank test. Probability (p) value of less than 0.05 was considered significant. The variables evaluated were age, gender, presence of thrombocytosis, pathological stage, tumor grade, nodal involvement and presence of tumor-related hydronephrosis.

\section{Results}

214 men (88.8\%) and 27 women (11.2\%) were included in the study. The mean age of the patients at surgery was 59.8 years (29-83 years). The mean followup was 34.8 months (SD: 36.66; range from 1 to 175$)$ for patients alive at last follow-up. Different techniques of urinary diversion were used. Ileal conduit was used in 97 patients; 58 patients developed orthotopic bladder using ileal segment; and orthotopic Mainz pouch was applied to 43 patients. While ureterocutaneostomy and ureterosigmoidostomy were the choice in 22 and 21 patients respectively. Sixty-four patients ( $26.6 \%)$ presented recurrence; 10 local (4.1\%), 11 systemic (22.1\%) and 43 showed both, local and systemic recurrence $(17.8 \%)$. The most frequent systemic metastasis sites in descending order were bone, liver and lung. The distribution of patients with recurrence according to the pathological stage is 
Table 1. The relationship between bladder tumor pathological stage and post-cystectomy recurrence rate

\begin{tabular}{|l|l|l|}
\hline $\begin{array}{l}\text { Pathological } \\
\text { Stage }\end{array}$ & Total No. of Patients & $\begin{array}{l}\text { No. of Patients Showed } \\
\text { Recurrence (\%) }\end{array}$ \\
\hline pT0 & 31 & $2(6.5 \%)$ \\
\hline pT1 & 52 & $6(11.5 \%)$ \\
\hline pT2 & 66 & $11(16.7 \%)$ \\
\hline pT3 & 57 & $28(49.1 \%)$ \\
\hline pT4 & 35 & $17(48.6 \%)$ \\
\hline Toplam & 241 & $64(26.6 \%)$ \\
\hline
\end{tabular}

$p<0.001$, Statistically relevant illustrated in table 1 . Tumors were classified as pT1 in 52 (21.6\%), pT2

Survival Functions

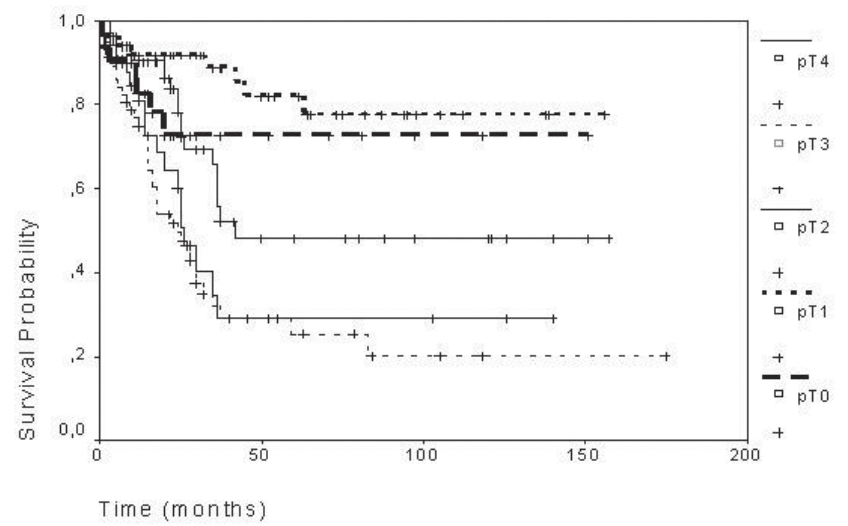

Figure 1. Kaplan-Meier estimates of bladder cancer-specific survival probabilities accordingto tumor stage in 241 patients treated with radical cystectomy

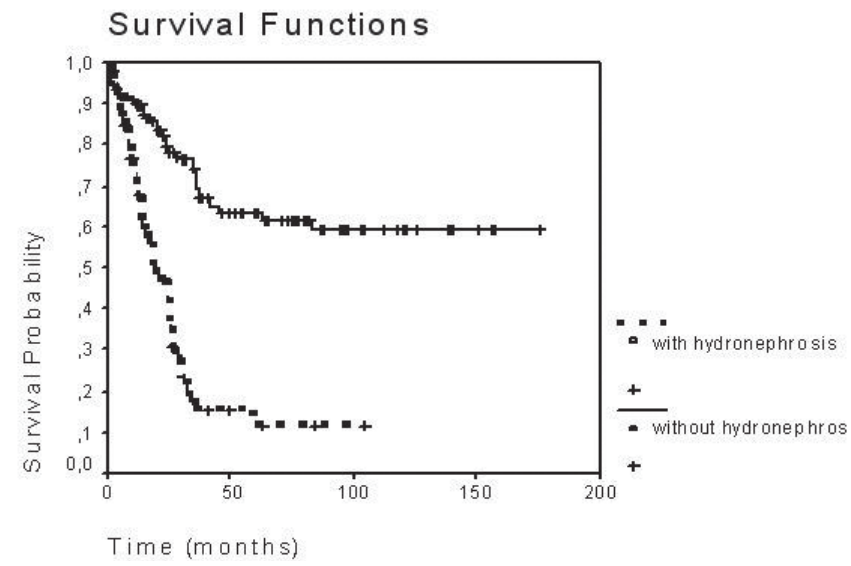

Figure 2. Kaplan-Meier estimates of bladder cancer-specific survival probabilities accordingto hydronephrosis status in 241 patients treated with radical cystectomy was found between pathological stage and survival rate $(\mathrm{p}<0.001$, Figure 1). Lymph node metastases were confirmed in 26 (10.8\%) patients and it was found to be 0\%, 0\%, 6.1\%, 26.3\% and 20.0\% for pT0, pT1, pT2, pT3 and pT4 respectively. Owing to the last finding, the relationship between pathological stage and lymph node involvement was stastistically relevant $(\mathrm{p}<0.001)$. Comparing tumor stage and grade, $28.8 \%$ of $\mathrm{pT} 1 ; 47 \%$ of $\mathrm{pT} 2 ; 78.9 \%$ of $\mathrm{pT} 3$ and $65.7 \%$ of pT4 patients had high grade or grade III tumor.

Prior to radical cystectomy, 52 patients $(21.5 \%)$ were diagnosed to have tumor-related hydronephrosis by imaging techniques (US, CT). 33 of them (63.5\%) developed recurrence post-operatively, while from the rest 189 patients (78.5\%) who had no pre-operative hydronephrosis, only 31 patients (16.4\%) developed recurrence post-operatively. Between the above two groups, a relationship of statistical relevance was found $(\mathrm{p}<0.001)$. Interestingly, tumor-related death was seen in 39 patients $(75 \%)$ of those with preoperative hydronephrosis. On the other hand, only 49 (26.5\%) out of 189 patients with no tumor-relatpT1, pT2, pT3 and p'T4 respectively and, eventually, a statistically relevant relationship

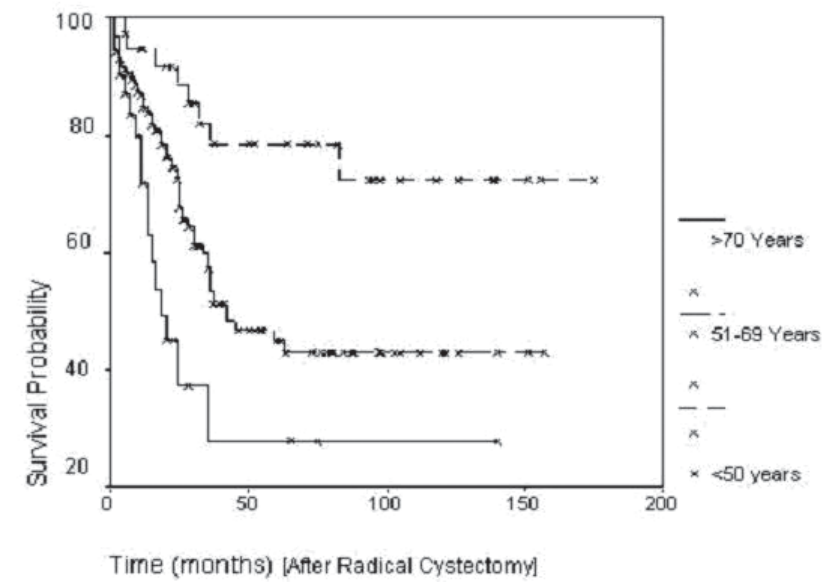

Figure 3. Kaplan-Meier estimates of bladder cancer-specific survival probabilities accordingto age at cystectomy in 241 patients treated with radical cystectomy 
Table 2. The relationship between blader tumor-related hydronephrosis and relevant pathological parameters

\begin{tabular}{|c|c|c|}
\hline & $\begin{array}{c}\text { Without } \\
\text { Hydronephrosis }\end{array}$ & With Hydronephrosis \\
\hline All & 189 & 52 \\
\hline \multicolumn{3}{|l|}{ pT } \\
\hline TO & 28 (14.8\%) & $3(5.8 \%)$ \\
\hline$T 1$ & $48(25.4 \%)$ & $4(7.7 \%)$ \\
\hline$T 2$ & 61 (32.3\%) & 5 (9.6\%) \\
\hline T3 & 31 (16.4\%) & $26(50.0 \%)$ \\
\hline$T 4$ & $21(11.1 \%)$ & $14(26.9 \%)$ \\
\hline \multicolumn{3}{|l|}{ Grade } \\
\hline 0 (no tumor) & 36 (19.0\%) & 13 (25.0\%) \\
\hline Low, I, II & 72 (38.1\%) & $6(11.5 \%)$ \\
\hline High, III & 81 (42.9\%) & 33 (63.5\%) \\
\hline \multicolumn{3}{|l|}{$\begin{array}{l}\text { Metastases to lymph } \\
\text { nodes }\end{array}$} \\
\hline No & $178(94.2 \%)$ & 37 (71.2\%) \\
\hline Yes & $11.0(5.8 \%)$ & $15(28.8 \%)$ \\
\hline
\end{tabular}

ed hydronephrosis prior to radical cystectomy died because of their bladder disease. Regarding the 5-year survival rate, only $11.5 \%$ of pre-cystectomy hydroneph- rotic patients survived the first 5 years, while as much as $63.4 \%$ of pre-operative hydronephrosis-free patients were alive for the same duration $(\mathrm{p}<0.001)$. At the time of surgery, lymph node metastases were found in 15 patients (28.8\%) in hydronephrotic group and 11 patients (5.8\%) in non-hydronephrotic group. The presence of hydronephrosis was associated with advanced $\mathrm{p} T$ stage, higher grade and lymph node metastases $(\mathrm{p}<0.001 ; \mathrm{p}<0.001$ and $\mathrm{p}<0.001$ respectively) (Table 2 ).

When analysis to age factor is conducted, regarding our clinic, the number of patients at radical cystectomy was found to be 38 for those aged 50 years and less (15.8\%, group I); 172 for 51-69 year-old (71.4\%, group II) and 31 for 70 year-old and above ( $12.8 \%$, grup III). For the above mentioned groups, 5-year survival rate was $78 \%, 45 \%$ and $28 \%$ for group I, II and III respectively. And, with the advance in age, statisticallyrelevant decrease in survival rate was observed $(\mathrm{p}<0.001)$. Comparing patient age, tumor stage and state of lymph node metastases; it is obvious that an advance in patient age is accompanied with a similar increase in tumor stage and lymph node metastases (Table $3)$. The analysis of the presence of thrombocytosis (plt > 450000 per mm3) and its effect on survival and tumor pathology showed that those with pre-operative thrombocytosis $(n=55)$ and those without it $(n=186)$ had no obvious difference in survival time $(35,36$

Table 3. The relationship between patient's age, 5-year survival rate and tumor's relevant pathological parameters

\begin{tabular}{|l|l|l|l|l|l|}
\hline Age & Patient No. & $\%$ & $\begin{array}{l}\mathbf{5} \text { year survival } \\
\text { rate }\end{array}$ & $\begin{array}{l}\text { Lymph node } \\
\text { metastases }\end{array}$ & Stage $\geq$ T3 \\
\hline$\leq 50$ & 38 & $15.8 \%$ & $78 \%$ & $2.6 \%$ & $31 \%$ \\
\hline $51-69$ & 172 & $71.4 \%$ & $45 \%$ & $11 \%$ & $36 \%$ \\
\hline$\geq 70$ & 31 & $12.8 \%$ & $28 \%$ & $19.4 \%$ & $54 \%$ \\
\hline
\end{tabular}


and 34, 72 months, respectively; $\mathrm{p}=0.998)$. Furthermore, comparing the presence of thrombocytosis, tumor stage and lymph node involvement revealed statisticallyirrelevant relationship $(p=0.316$, $\mathrm{p}=0.147)$. Multivariate analysis showed that the lymph node metastases, advanced age and hydronephrosis are the parameters which directly affecting cancer specific survival $(\mathrm{p}<0.001, \mathrm{p}=0.0047$, $\mathrm{p}=0.0272$, respectively).

\section{Discussion}

Bladder carcinoma is the second most frequent urogenital tumor disease, more than $90 \%$ of which are transitional cell carcinoma. Nearly 30\% of these tumors already are or will progress into muscle invasive tumor during their follow up (7). Invasive bladder carcinoma is a fatal disease (i.e. nearly $85 \%$ mortality rate is seen in untreated patients) (8). Currently, radical cystectomy is the gold-standrad in treating invasive bladder tumors (3). During the last few decades, due to increasing clinical data and surgical experiences regarding radical cystectomy and newely-developed urinary diversion maneuvers, techniques involved in radical cystectomy surgery has been changed dramatically. Apart from advances in surgical techniques, advances in anesthesia and post-operative care led to a tremendous decline in surgery-related morbidity and mortality. Peri-operative mortality rate of $20-30 \%$ in 1970 s has currently decreased to less than $2 \%(9,10)$. In many large series, the introduction of radical cystectomy in the treatment of mucle-invasive bladder carcinoma has extremely changed its natural fatal course and a $45 \%$ $66 \%$ 10-year survival rate become achievable post-cystectomy (7, $9,10,11)$. In the largest series to date Stein et al reported 5-year recurrence-free and overall survival rates of $68 \%$ and $60 \%$, respectively, in patients who underwent radical cystectomy with bilateral lymphadenectomy in a 26-year period (7). In an another single institution series of 507 patients who underwent surgery between 1985 and 2000 Madersbacher et al reported 5-year recurrence-free and overall survival rates of $62 \%$ and 59\%, respectively(11). The Pathological stage of the primary tumor and the presence of lymph node metastases are crucial factors in determination of post-cystectomy prognosis and survival $(7,9-12)$.

In our series, as mentioned before, the 5-year survival rate was found to be $72.9 \%$, $\% 77.6 \%, 48.0 \%$, $25.4 \%$ and $28.8 \%$ for pT0, pT1, pT2, pT3 and pT4 respectively. It is clearly seen that survival rate drops steeply when perivesical invasion is present ( $\geq \mathrm{pT} 3$ ). Moreover, it is found that $6.5 \%, 11.5 \%$, $16.7 \%, 49.1 \%$ and $48.6 \%$ were the local recurrence and/or metastasis rate for p'0, p'1, p'T2, p'3 and pT4 respectively $(\mathrm{p}<0.001)$. Lymph node involvment, also, increase with increase in pathological stage. Lymph node metastases in pT3 or more (pT3: \%26.3, pT4: \%20), is remarkably higher $(\mathrm{P}<0.001)$ than in $\mathrm{p} T 2$ or less (pT0 and pT1: \%0, pT2: \%6.1). Surprisingly, the survival in pT4 is slightly higher than in pT3. This condition results from staging prostatic urethra invasion as T4a, which shows much better course than prostatic stromal invasion (T4). Esrig et al, classified 143 patients with postcystectomy pathological stage of pT4 into two groups; prostatic stromal invasion and prostatic urethral invasion. The first group had 5-year recurrence-free and overall survival of $25 \%$ and $21 \%$; while the survival of the second group was $64 \%$ and $55 \%$ respectively (13).
For this reason, we think that $\mathrm{T} 4 \mathrm{a}$ to be re-evaluated and staged accordingly.

Pelvic node involvement has been demonstrated to be a highly ominous prognostic factor in all series $(3,7,10-15)$. In an analysis of 130 patients, Soloway et al observed that 5-year survival rates were $82 \%$ for patients with superficial tumors, $65 \%$ for those with T2 and $28 \%$ for patients with T3/T4, while patients with lymph node involvement presented a 5-year survival rate of $18 \%$ against $65 \%$ for patients presenting no lymph node involvement (14). The reported incidence of regional nodal involvement varied between 14 and 27\% and this incidence correlated with the P-stage of the primary tumors (16). In our series, $10.8 \%$ of the patients had metastatic pelvic nodal involvement and the rate of having nodal involvement was significantly higher $(\mathrm{p}<0.001)$ in patients with advanced stages ( $\geq$ pT3) than in those with early stages.

The incidance of hydronephrosis associated with bladder carcinoma ranges from $7.2 \%$ to $54.1 \%(17,18)$. In our series, this rate was found to be $21.5 \%$. Therefore, hydronephrosis is a frequent complication of bladder carcinoma. However, its prognostic value in patients with bladder carcinoma is controversial (17- 20). In 1956, Nichols and Marshal first reported that seven of their ten patients with ureteral obstruction and transitional cell carcinoma of the bladder had high grade and high stage bladder carcinoma (20). Since then, further studies have described the negative associations of hydronephrosis in bladder carcinoma including the presence of metastatic disease, poorer differentiation of tumours, poorer survival and treatment outcome $(17,18,19,21)$. In one study, Leibovitch et al, analysed 
122 patients with invasive bladder carcinoma, of these 122 cases, 82\% underwent radical cystectomy and only half of them had a pelvic lymph node dissection. In that series, 5-year cancer-specific survival rates were $65.9 \%$ and $32.2 \%$ for patients without and with hydronephrosis, respectively $(\mathrm{p}<0.005)$ (18). In our series, 5-year cancerspecific survival rates for patients without hydronephrosis were nearly same (63.4\%) as Leibovitch et al's study. However, this rate was obviously lower in our study for patients with hydronephrosis (11.6\%). Our results showed that, hydronephrosis correlates well with advanced tumor stage and a significantly lower cancer-specific survival rate. As the correlation between clinical and pathological staging is poor in invasive bladder carcinoma, the finding of hydronephrosis by indicating advanced stage may help the clinicians in decision-making process.
In our series, we found that advanced chronological age to be significantly associated with adverse pathological features and poorer disease-specific outcomes. In 2005, Clark et al, analyzed age as a categorical variable by decade, find an increased risk of extravesical disease, disease recurrence, and poorer overall survival among their older patients (22). More recently, in a large cystectomy series, Nielsen et al found that higher chronological age to be independently associated with pathologically advanced disease and bladder cancer-specific mortality after cystectomy (23). The finding of an increased risk of extravesical disease and worse cancer-specific survival among these elderly patients may possibly be due to a reluctance to treat these patients with major surgery and this may cause a delay in undergoing surgery. Other explanation, might be the difference in the biology of tumors stratified by age.
In our series, gender and pre-cystectomy presence of thrombocytosis showed no effect on prognosis.

In this retrospective analysis, five main independent prognostic factors have been identified:

pathological stage, grade, nodal involvement, age and upper obstructive uropathy. These factors significantly influenced the disease-free survival of patients who survived radical cystectomy for bladder carcinoma. But multivariate analysis showed that the only lymph node metastases, advanced age and hydronephrosis are the parameters which directly affecting cancer specific survival. In this series, it is clearly shown that good results could be obtained if radical cystectomy is the treatment of choice for patients with early diagnosed invasive bladder carcinoma $(<\mathrm{pT} 3)$. On the other hand, radical cystectomy is considered not enough for patients having locally-invasive non-metastatic bladder carcinoma (p'3-pT4)

results in 1,026 cases. J Urol 1997; 158(2):393-9.

6. Haleblian GE, Skinner EC, Dickinson MG, et al. Hydronephrosis as a prognostic indicator in bladder cancer patients. J Urol 1998; 160: 2011-4.

7. Stein JP, Lieskovsky G, Cote R, et al.: Radical cystectomy in the treatment of invasive bladder cancer: longterm results in 1,054 patients. J Clin Oncol. 2001; 19: 666-75.

8. Prout G, Marshall VF. The prognosis with untreated bladder tumors. Cancer 1956; 9: 551-8.

9. Hautmann RE, Gschwend JE, de Petriconi RC, Kron M, Volkmer BG. Cystectomy for transitional cell carcinoma of the bladder: results of a surgery only series in the neobladder era. J Urol. 2006;176(2): 486-92.

10. Ghoneim MA, el-Mekresh MM, el-Baz MA, el-Attar IA, Ashamallah A. Radical cystectomy for carcinoma of the bladder: critical evaluation of the
11. Madersbacher S, Hochreiter W, Burkhard F, et al. Radical cystectomy for bladder cancer today a homogeneous series without neoadjuvant therapy. J Clin Oncol 2003; 21: 690-6.

12. Frazier HA, Robertson JE, Dodge RK, Paulson DF. The value of pathological factors in predicting cancerspecific survival among patients treated with radical cystectomy for transitional cell carcinoma of the bladder and prostate. Cancer 1993; 71: 3993-9.

13. Esrig D, Freeman JA, Elmajian DA, et al. Transitional cell carcinoma involving the prostate with a proposed staging classification for stromal invasion. J Urol. 1996;156(3):1071-6.

14. Soloway MS, Lopez AE, Patel J, et al. Results of radical cystectomy for transitional cell carcinoma of the bladder and the effect of chemothe- 
rapy. Cancer. 1994; 73: 1926-31.

15. Lerner SP, Skinner DG, Lieskowsky $\mathrm{G}$, et al. The rationale of en bloc pelvic node dissection for bladder cancer patients with nodal metastases: long-term results. J Urol 1993; 149: 758-63.

16. Mokhtar AA, El-Sebaie MM, Elkum N. Predictors of Outcome after Radical Cystectomy for Bladder Cancer in Saudi Patients; Single Institution Experience. Journal of the Egyptian Nat. Cancer Inst., 2004; 16 (3): 137144.

17. Bartsch GC, Kuefer R, Gschwend $\mathrm{JE}$, et al. Hydronephrosis as a prog- nostic marker in bladder cancer in a cystectomy-only series. Eur Urol 2007; 51: 690-98.

18. Leibovitch I, Ben-Chaim J, Ramon $\mathrm{J}$, et al. The significance of ureteral obstruction in invasive transitional cell carcinoma of the urinary bladder. J Surg Oncol 1993; 52: 31-5.

19. Yang $M H$, Yen CC, Chen PM, et al. Prognostic-factorsbased riskstratification model for invasive urothelial carcinoma of the urinary bladder in Taiwan. Urology 2002; 59: 232-9.

20. Nichols JA, Marshall VF. The treatment of bladder carcinoma by local excision and fulguration. Cancer 1956; 9: 559-65.

21. Haleblian GE, Skinner EC, Dickinson MG, et al. Hydronephrosis as a prognostic indicator in bladder cancer patients. J Urol 1998; 160: 2011-4.

22. Clark PE, Stein JP, Groshen SG, et al. Radical cystectomy in the elderly. Cancer 2005; 103(3): 546-52.

23. Nielsen ME, Shariat SF, Karakiewicz PI, et al. Advanced age is associated with poorer bladder cancer-specific survival in patients treated with radical cystectomy. Eur Urol 2007; 51: 699-708 